\title{
The Application of Input Hypothesis and Affective Filter Hypothesis in Colleges English Listening Teaching
}

\author{
XU Min \\ GZ Vocational College of Science and Technology, 510550 \\ hunter2011@foxmail.com
}

Keywords: Input hypothesis; Affective filter hypothesis; English listening teaching

\begin{abstract}
Listening is a crucial components and important task in English teaching and it is a vulnerable spot for vocational college students in their language study as well. On the analysis of the current situations of English listening teaching at colleges, the paper aims to find a way to improve listening comprehensive ability of students at vocational colleges from the perspective of Krashen's input hypothesis and affective filter hypothesis
\end{abstract}

\section{Introduction}

Listening is a basic skill of practical application of language, and effective listening is not only one of the important means of effective input, but also plays an important role in the process of learning a new language. Basic requirements for College English (2006) has also proposed giving priority to utility and laying emphasis on application. Therefore, listening teaching has been becoming increasingly concerned in foreign language teaching. The listening training can cultivate the students' listening skills, improve their listening comprehension, and promote their intelligence and practical application of English, but facing the severe situation of teaching, English teachers need effective strategies to improve the quality of listening teaching at higher vocational colleges.

\section{Krashen's input hypothesis and affective filter hypothesis}

Krashen put forward "monitor model" in the early 1970s, and then in the middle of 1980s, he made further expansion and formed "the input hypothesis model" with the input hypothesis as the center. Specifically, "input hypothesis model” is composed of five interrelated core hypotheses, namely the acquisition-learning hypothesis, the natural order hypothesis, the monitor hypothesis, the input hypothesis and affective filter hypothesis, which constitute an organic whole and complement each other. The article will focus on the latter two hypotheses.

The input hypothesis. Krashen (1985) argues that only when the acquisition is in contact with the comprehensive input, that is, the input language is above the learners' existing level and the overall difficulty of it can be understood, can they learn language effectively. This is the famous mode " $\mathrm{i}+1$ ", in which " $\mathrm{i}$ " represents the existing level of the language learners while " 1 "stands for the new language material slightly higher than the current level. Krashen proposes that the ideal input should share the following characteristics: comprehensibility, relevancy, ungrammatical sequence, and enough input---the principle of " $i+1$ ".

Affective filter hypothesis. Affective filter hypothesis---the number of learners' acquisition of comprehensive input is affected by affective filter, including motivation, self-confidence and anxiety, etc. In other words, the emotional factors of language learners profoundly influence the effect of their acquisition (Krashen, 1982). Typically, the learners with clear motivation, strong self-confidence and measurable anxiety can acquire more input because of the low filtering effects on language input. On the contrary, the language learners have less input as a result of the high filtering effects. In language teaching, therefore, the degree of students' affective filtration should be reduced to effectively conduct language input in harmonious environment. 


\section{Present situations of English listening teaching at vocational colleges}

In terms of the previous researches combined with the author's own teaching experience in English listening teaching, some problems are observed as follows:

In the aspect of students. (1) Weak English foundation and low learning interest. As the expansion of college enrollment and increasing number of vocational colleges, the learning foundation of students is relatively poor, especially in English such as lacking necessary knowledge of English phonetics and not mastering enough English pronunciation rules, which influence the students' understanding of listening materials and making output seriously. In addition, students have difficulty in understanding words of the listening practice, which will affect the listening comprehension correctly. These negative factors will make students lost interests in English listening training. What's more, they even disgust and less actively participate in the listening training, mostly struggling to keep up under the supervision of teachers.

(2) The influence of affective factors. Krashen (1985) argues that "The amount of language input and the degree of learners' affective filter play an important role in acquiring information in the brain responsible for language." Because of weak foundation of the students and few understanding of the content, they are inclined to feel nervous, tired and irritable in class. And the more they don't understand, the more they would feel at a loss, which becomes the main obstacle to improving their listening ability. In the long term, the students will be frustrated in the process of English listening and restrain them from improving their competence and using English.

(3) Insufficient background knowledge of listening materials. The social and cultural background knowledge related to listening materials is effective to reduce the dependence of the students on sound and improve their ability of description and reasoning strategies in some extent. As a matter of fact, students at vocational colleges know little about social and cultural knowledge of English-speaking countries. Once encountering this kind of knowledge in the training, they often not fully understand the content after listening, which influences the comprehension of the overall materials.

(4) Lacking correct listening strategies and methods. We find that the students lack some necessary listening strategies in daily teaching practice such as making no plan in listening exercises, not browsing questions and items in advance to predict the content, or not taking notes in the process of listening. They even blindly believe that understanding every sentence and word is enough, leading to forgetting the previous content after acquiring the rest, affecting the attainment of the overall materials and restricting the improvement of students' listening level in some degree.

In the aspect of teachers. (1) Outmoded teaching pattern and simplex teaching method. English classes at vocational colleges are obliged to focus on practical application, but some teachers still adopt the traditional teaching method--- listening material, doing exercises and checking answers. They do not pay attention to the particularity of listening course. At the same time, content is relatively monotonous with rare supplementary materials, which is a listening test instead of training in fact and in which teachers' leading role and students' main-body role can not be worked effectively as well. Of course, there would be no possibility to cultivate students' English listening and communicative ability in the real scene. Although having noticed the students' listening level is influenced by their affective factors, knowledge and the application of listening strategies and so on, some teachers do not give specific guidance in daily teaching such as how to overcome the tension, how to practice listening after class.

(2)Traditional viewpoints, insufficient attention to English listening. According to the research of River and Temperly (1999), training time spent on listening in the language communication training should be $45 \%$ of the total time compared with that on reading, speaking and writing. However, English listening teaching has not gotten deserved attention at vocational college English classes. On the contrary, teachers spend a lot of time and energy on reading, writing while very few on effective listening training because many of them believe that these exercises do not tally with the English test in difficulty or the speed and content of the practice but also do not meet the test requirements, resulting in their ignoring the listening part and directly coming into the text learning. 
Even though some teachers use the materials, students are only to listen to the tape and check answers. In this process, teachers just send the tape script to students if they do not understand, and ask them to read or explain the new words and difficult sentences, which neglect the training of the students' listening skills and cultural literacy.

\section{The application of input hypothesis and affective filter hypothesis to English listening teaching}

In accordance with the three steps of listening designed by English listening teaching experts Mary Underwood (1989) on the basis of the theory of listening comprehension and psychological pattern of memory, the concrete application of above hypotheses to English listening teaching is as follows:

Pre-listening. (1) Integrating the listening materials. The formula " $\mathrm{i}+1$ " shows that effective language acquisition can be gotten on condition of enough language input, so the teachers should integrate listening materials according to the language level of the students before class.

Teachers need to rearrange the teaching materials, making it more suitable for the development of the students' English ability and their cognition. If input information is not understandable, it is a waste of time completely and even likely to influence students' self-confidence. What's more, teachers should select the coherent and understandable listening materials that can attract students' interests, and try to optimize the listening materials, speech patterns and understandability of complexity.

(2) Preparing background information. Psychologists believe that listening effect is subject to psychology. People will listen to the materials more attentively when they are interested in them. Their psychological development is from noticing to accepting and understanding, otherwise they will feel bored and are interrupted by distraction, unwilling to continue to accomplish the rest steps consistently. How can we attract the attention of students? It is very important to let the students be familiar with and understand the context related to listening materials. Different rules applied for different types of communication context which is a place and stage for communication, therefore, the analysis and study of language must be based on the relied-on context.

Teachers should supplement relevant cultural background information related to the listening materials, which can not only stimulate students' interests in learning but also help them overcome cultural differences caused by communication barriers and improve their cognition and understanding abilities in language learning. At the same time, the teacher can also provide relevant English videos to the students with advanced multimedia and network technology according to the content of the textbook, making students be familiar with the English phonetics, slang, pragmatic habits, etc., which is convenient for them to acquire comprehensible input in real environment and strengthen their spoken English effectively through the imitation practice. Besides, teachers can encourage students to learn autonomously ---asking them to actively look for relevant materials, read widely, and then invite them to show their achievements or have a discussion and make a summary, which mobilize the students' initiatives greatly.

While-listening. (1) Cultivating strategies of listening comprehension. As successful utilization of strategies will improve the effects of listening, teachers should pay attention to training students' listening strategies and provide opportunities for them to use these skills. English listening strategies are mainly meta-cognitive strategy and cognitive strategy. The former one refers to students' strategies of effective monitoring and controlling the whole process of learning, such as the overall plan of doing listening exercises, analysis and evaluation of their own performance, etc. And the latter one means students' methods and techniques of processing input materials, which mainly are divided into bottom - up strategies, such as taking notes, grasping the key words, etc., and top-down kinds e.g., guessing meanings of words according to the context, judging implied meanings through speakers' tone, etc. We certainly cannot talk only about theories for it is more important to provide the practicing chances to students continuously.

(2) Strengthening students' confidence and reducing their anxiety. Krashen's affective filter hypothesis holds that people with strong self-confidence, huge motivation can get more acquisition, 
and low anxiety is more helpful to second language acquisition. In addition, some previous studies have shown learner's anxiety is inversely proportional to language acquisition. Hence the teachers should fully realize the effects of the emotional factors on listening input. During the listening teaching, teachers should improve students' self-confidence and cultivate their correct learning motivation, bringing down filtering to a minimum state and laying a solid foundation for the output. Furthermore, teachers should also develop the students' patience, help them overcome the psychology of quick successes and grasp profound language acquisition in order to obtain effective input. When creating a harmonious environment, of course, the teacher cannot let them do as they like in class without goals and pressures.

Post-listening. (1) Guiding students to analyze and solve problems. After the listening practice, the teacher should guide students to make good use of the evaluation strategy among the meta-cognitive strategy and let the students themselves properly make an assessment of the learning process then adjust learning strategies. At first, the students analyze problems in the process of listening comprehension and put forward the solutions under the guidance of the teachers. Then they are asked to assess themselves, such as whether they have used appropriate strategies during the practice, what is the cause of the success or failure, and so on. The students will be more confident to request for themselves when they are aware of their progresses, and will more actively strive for the target. This diagnostic post-listening not only improves students' listening skills but also their own comprehensive qualities.

(2) Combining listening training with other language practice. Listening teaching is not to look for the answer but to cultivate the students' English comprehensive abilities. Listening, speaking, reading and writing are inseparable, therefore, teachers should consider listening course as the integrated curriculum which means combining listening with other language skills. After listening class, the teacher can arrange language materials to make dialogues, debates, speeches, etc. aiming to promote the students' oral English through listening and enhancing students' communicative competences. In the meantime, the students can be required to read related articles, which is beneficial for them to consolidate vocabulary and extend their knowledge, familiarize with ideas and styles of English writing as well.

\section{References}

[1] Cook, V. (2000). Linguistics and Second Language Acquisition. Beijing: Foreign Language Teaching and Research Press.

[2] Department of Higher Education. (2006). Basic requirements for College English. Beijing: Higher Education Press.

[3] Ellis, R. (2000). Second Language Acquisition. Shanghai: Shanghai Foreign Language Education Press.

[4] Krashen, S. (1982). Principles and Practice in Second Language Acquisition. Oxford: Pergamon Press

[5] Krashen, S. (1985). The Input Hypothesis Issues and Implications. London: Longman.

[6] Li, R. (2003). Factors that Chinese Students Believe to Affect Their Oral Fluency. Teaching English in China, 52, 23-27. Beijing: Foreign Language Teaching and Research Press.

[7] Man, L. (2005). English Listening and Speaking Teaching Based on Input and Output Theory. Journal of Taizhou University, volume 27, number 2, 54-57.

[8] Underwood, M. (1989). Teaching Listening. London: Longman.

[9] River, W. M. \& Temperly, M. S. (1999). A Research on Language Skills. Cambridge: Cambridge University Press. 
[10] Saville-Troike, M. (2008). Introducing Second Language Acquisition. Beijing: Foreign Language Teaching and Research Press.

[11] Thompson, I. \& Rubin, J. (1996). Can Strategy Instruction Improve Listening Comprehension? Foreign Language Annals, 3, 31-42.

[12] Wang, L. F. (2009). Introducing Second Language Acquisition. Beijing: Higher Education Press.

[13] Wang, H.J. (2004). Krashen's Input Hypothesis of L2 and the Streaming Teaching of Listening. Journal of Changsha University, volume 18, number 3, 118-120.

[14] Wen, Q. F. (2005). Research Methods in Applied Linguistics and Thesis Writing. Beijing: Foreign Language Teaching and Research Press.

[15] Wu, W. Q. (2010). The Application of Input Hypothesis to the Teaching of Listening and Speaking of College English. Asian Social Science, volume 6, number 9,137-141.

[16] Xu, F. (2010). The Role of Input and Interaction in Second Language Acquisition. Cross-Cultural Communication, volume 6, number 1, 11-17.

[17] Zhang, S. M. (2009). The Role of Input, Interaction and Output in the Development of Oral Fluency. English Language Teaching, volume 2, number 4, 91-100. 